\title{
OPTIMALISASI DAYA KOAGULASI SERBUK BIJI KELOR (Moringa oleifera) PADA LIMBAH CAIR INDUSTRI TAHU
}

\section{OPTIMIZATION POWER OF COAGULATION Moringa oleifera SEEDS POWDER IN WASTE WATER OF TOFU INDUSTRY}

\author{
Meirita Sari \\ Program Studi Teknologi Pertanian Universitas Dehasen \\ Email: sari_meirita@yahoo.com
}

\begin{abstract}
ABSTRAK
Koagulasi-flokulasi merupakan salah satu solusi alternatif dalam menangani pencemaran lingkungan yang disebabkan oleh limbah cair industri tahu. Telah dilakukan penelitian tentang pemanfaatan serbuk biji kelor sebagai koagulan alami yang ramah lingkungan dengan varian kadar kelor dan waktu kontak pengadukan cepat. Penelitian ini bertujuan untuk mengetahui kadar serbuk biji kelor dan waktu kontak yang dapat memberikan hasil optimum dalam mengendapkan TSS limbah cair industri tahu. Dalam penelitian ini, tahapan yang dilakukan ialah preparasi sampel (limbah tahu), preparasi serbuk biji kelor, uji variasi kadar serbuk kelor dan waktu kontak terhadap pengendapan padatan tersuspensi (TSS). Hasil penelitian menunjukkan bahwa serbuk biji kelor pada kadar 0,5\% (b/v) dalam sampel limbah dan waktu kontak pada pengadukan cepat selama 7 menit dapat mengendapkan TSS pada kondisi optimum sebesar $3230 \mathrm{mg} / \mathrm{L}$.
\end{abstract}

Kata Kunci : Koagulasi, Biji Kelor (Moringa oleifera), Limbah Cair Industri Tahu, Padatan Tersuspensi (TSS).

\section{ABSTRACT}

Coagulation-flocculation is one of the alternative solutions to minimize environmental pollution caused by wastewater of tofu industry. A study concerning the use of moringa oleifera seeds powder as natural coagulant, which is environmentally friendly, with variation of concentration of moringa oleifera seeds and contact time (stirring) was done. The aims of this study is to determine optimum concentration of moringa seeds powder and contact time to give optimum results in precipitating total suspended solid in wastewater of tofu industry. In this study, the steps being taken were; preparation of samples (wastewater of tofu industry), preparation of moringa oleifera seeds powder, concentration optimalization of moringa seeds powder and the contact time of the sedimentation of total suspended solids (TSS). The results showed that the concentration of moringa seeds powder of $0.5 \%(w / v)$ in the waste samples and stirring time of 7 minutes were the optimum conditions to precipitate the TSS with $3230 \mathrm{mg} / \mathrm{L}$ of precipitate.

Keywords: Coagulation, Moringa oleifera Seeds, Wastewater of Tofu Industry, Total Suspended Solid. 


\section{PENDAHULUAN}

Masalah lingkungan yang tampak nyata akhir-akhir ini sebagian besar disebabkan oleh kegiatan manusia, mulai dari kegiatan sehari-hari hingga kegiatan industri. Perkembangan industri dewasa ini nampaknya bertanggung jawab atas kerusakan lingkungan sebagai akibat dari limbah yang dihasilkan pada tiap tahapan produksi. Limbah cair industri yang paling banyak menyumbang pencemaran lingkungan sekitar perindustrian.

Kegiatan industri yang berkembang cukup pesat saat ini ialah industri di bidang pangan, salah satunya industri tahu yang tersebar luas di setiap kota di Indonesia. Pada tiap tahapan proses produksi tahu menghasilkan limbah berupa limbah cair dan limbah padat. Saat ini limbah padat telah banyak dimanfaatkan sebagai pakan ternak. Namun tidak demikian dengan limbah cair yang masih dibuang langsung ke lingkungan perairan sekitar.

Wiryani (2005) menyatakan bahwa limbah cair tahu yang belum mengalami proses pengolahan mengandung padatan tersuspensi maupun terlarut dalam jumlah yang cukup tinggi. Limbah cair ini merupakan koloid dengan partikel-partikel berdiameter sekitar $1 \mathrm{~nm}\left(10^{-7} \mathrm{~cm}\right)$ hingga $0,1 \mathrm{~nm}\left(10^{-8} \mathrm{~cm}\right)$. Partikel-partikel ini tidak dapat mengendap dalam periode waktu yang wajar dan tidak dapat dihilangkan dengan proses perlakuan fisika biasa (Sumardjo, 2006: 539). Umumnya limbah cair ini langsung dibuang ke lingkungan perairan tanpa pengolahan terlebih dahulu. Hal ini berpengaruh terhadap kelangsungan makhluk hidup air. Jika hal ini dibiarkan maka akan terjadi penurunan jumlah habitat yang sesuai untuk makhluk hidup air yang mengarah pada penurunan jumlah individu makhluk hidup secara keseluruhan. Ketidakseimbangan lingkungan baik kimia, fisika maupun biologis dari perairan yang setiap hari menerima beban limbah dari proses produksi tahu ini, akan dapat mempengaruhi ekosistem di perairan tersebut. Oleh karena itu perlu adanya upaya penanggulangan limbah.

Ada beberapa cara yang dapat dilakukan untuk menangani limbah cair yang dihasilkan dari industri tahu, salah satunya ialah koagulasi. Koagulasi merupakan proses destabilisasi koloid dalam limbah cair dengan menambahkan bahan kimia (koagulan) yang diakhiri dengan pembentukan partikel berukuran besar (flok) (Sumardjo, 2006). Penggabungan inti flok menjadi flok berukuran lebih besar yang memungkinkan partikel dapat mengendap (Pudjaatmaka, 2002: 249). Cara ini dapat 
dijadikan sebagai solusi alternatif dalam pengolahan limbah cair industri tahu secara kimiawi.

Salah satu koagulan alami yang dapat dijadikan sebagai alternatif pengolahan limbah cair yang ramah lingkungan yaitu biji kelor (Moringa oleifera). Kelor merupakan tumbuhan jenis perdu yang memiliki manfaat pada setiap bagiannya. Biji kelor yang sudah tua dapat dijadikan sebagai koagulan penjernih air dan limbah cair. Biji kelor mengandung zat aktif yang dapat membantu menurunkan gaya tolak menolak antara partikel koloid dalam air (Sutherland, 1994). Zat aktif dalam biji kelor dapat menyebabkan destabilisasi partikel koloid (limbah cair) yang dapat terjadi melalui mekanisme yang disebut dengan jembatan antar partikel. Dalam mekanisme ini, ion-ion atau koloid bermuatan positif yang digunakan bersumber dari polimer. Polimer adalah senyawa karbon rantai panjang (linear atau cabang). Polimer memiliki banyak tempat aktif sepanjang rantainya dimana partikel koloid dapat berinteraksi dan teradsorbsi. Apabila dua atau lebih partikel teradsorbsi sepanjang rantai polimer, suatu jembatan partikel akan dibentuk. Jembatan partikel tersebut kemudian akan jalin-menjalin dengan jembatan partikel lain selama proses flokulasi dan mengendap dengan mudah sebagai suatu hasil dari pertambahan ukuran. Polimer yang digunakan dalam proses destabilisasi partikel koloid sering disebut dengan polielektrolit (Montgomery, 1985: $565)$.

Dari uraian tersebut, maka biji kelor berpotensi sebagai koagulan alami dalam menurunkan kadar TSS limbah cair industi tahu. Penelitian ini diarahkan pada faktorfaktor yang dapat mempengaruhi keberhasilan suatu proses koagulasi antara lain kadar koagulan optimum dan waktu kontak optimum. Amdani (2004) melaporkan bahwa $\mathrm{pH}$ dan kadar koagulan biji kelor berpengaruh nyata terhadap penyisihan kekeruhan limbah cair industri pencucian jeans. Derajat keasaman $(\mathrm{pH})$ optimum koagulasinya adalah 3 (tiga) dengan kekeruhan tersisihkan 83,03\%. Kadar optimum biji kelor adalah 120 $\mathrm{mg} / 250 \mathrm{~mL}$ atau $480 \mathrm{mg} / \mathrm{L}$ dengan kekeruhan yang tersisihkan sebesar 92,21\%. Sehingga penggunaan koagulan alami seperti biji kelor dapat menjadi teknologi alternatif dalam pengolahan limbah cair yang memanfaatkan potensi alam.

Berdasarkan latar belakang tersebut, maka peneliti tertarik untuk melakukan penelitian tentang optimalisasi daya koagulasi serbuk biji kelor (Moringa 
oleifera) pada limbah cair industri tahu. Penelitian ini berfokus pada optimalisasi kemampuan serbuk biji kelor (Moringa oleifera) dalam mengendapkan TSS limbah cair industri tahu. Dengan dilakukannya penelitian ini, maka diharapkan adanya pengolahan limbah cair tahu dengan menggunakan koagulan alami yang berkualitas, mudah didapat, praktis, dan ramah lingkungan sekaligus menambah nilai ekonomis dari keanekaragaman hayati yang ada di Indonesia, sehingga bisa menjadi motivasi masyarakat untuk membudidayakan dan mengembangkan sumber daya alam secara baik.

\section{METODE PENELITIAN}

Penelitian ini dilaksanakan di Laboratorium Agronomi Fakultas Pertanian Universitas Bengkulu. Alat-alat yang digunakan dalam penelitian ini blender, stopwatch, oven, neraca analitik, $\mathrm{pH}$ meter digital, magnetic stirer, ayakan tlyer, pipet volumetric, bola hisap, corong, erlenmeyer, beaker glass, sudip, kertas saring no 45 . Bahan-bahan yang digunakan dalam penelitian ini adalah: Limbah cair tahu, biji kelor, Aquades.

Langkah pertama yang dilakukan dalam penelitian ini ialah penyiapan sampel limbah cair tahu yang berasal dari industri tahu daerah tebeng kota Bengkulu yang diendapkan selama satu malam. Hal ini bertujuan untuk menstabilkan sampel sebelum diteliti. Kemudian bahan koagulan juga disiapkan, yaitu biji kelor (Moringa oleifera) yang diambil di daerah Cenggeri Bengkulu. Untuk membuat bahan koagulan, buah kelor yang sudah matang dan kering secara alami disortir, lalu bijinya dikeluarkan dari dan dibersihkan. Biji dengan cangkangnya yang bersih diblender hingga menjadi serbuk dan diayak dengan ayakan tyler berukuran 200 mesh lalu dikeringkan dalam oven pada suhu $105^{\circ} \mathrm{C}$ selama 30 menit untuk menghomogenkan dan menurunkan kadar airnya hingga konstan.

Selanjutnya, dilakukan uji laboratorium untuk mendapatkan kadar dan waktu kontak optimum koagulasi/flokulasi menggunakan serbuk biji kelor yang efektif dalam mengendapkan TSS. Dilakukan pengukuran $\mathrm{pH}$ awal limbah cair tahu. Tahapan penelitian ialah sebagai berikut:

1. Dimasukkan masing-masing $100 \mathrm{ml}$ sampel limbah cair tahu ke dalam lima beaker glass.

2. Ditambahkan koagulan serbuk biji kelor sebanyak (variasi kadar: 100mg, 300mg, 500mg, 700mg, 900mg) ke dalam masing-masing beaker glass. 
3. kemudian larutan diaduk dengan cepat (100 rpm) selama 1 menit dan diikuti pengadukan lambat (40 rpm) selama 10 menit.

4. Setelah pengadukan, dilakukan pengendapan selama \pm 24 jam.

5. Hasil diambil dan dilakukan pengukuran TSS.

6. Perlakuan (No 1-6) diulangi dengan prosedur yang sama dengan variasi waktu kontak pada saat pengadukan cepat selama 3 menit, 5 menit, 7 menit, 9 menit.

Sedangkan pengukuran TSS dilakukan dengan cara beriku:

1. Kertas saring dipanaskan di oven pada suhu $\pm 105^{\circ} \mathrm{C}$ selama 30 menit.

2. Kemudian didinginkan dalam desikator selama 15 menit lalu ditimbang dengan cepat.
3. $100 \mathrm{~mL}$ sampel yang sudah diberi perlakuan disaring dengan menggunakan corong penyaring yang sudah ada kertas saring didalamnya.

4. Kertas saring + residu dipanaskan dalam oven pada suhu $105^{\circ} \mathrm{C}$ selama 1 jam.

5. Kertas saring + residu didinginkan dalam desikator selama 15 menit, kemudian ditimbang dengan cepat.

Untuk melihat kesesuaian data hasil eksperimen dengan nilai yang diharapkan maka dilakukan analisis grafik menggunakan teknik error bar (batang ralat). Teknik ini membantu dalam mengamati seberapa bagus setiap data mengikuti kurva atau garis pada grafik. Teknik ini dilakukan dengan menggunakan program Microsoft excel 2007.

Tabel 1. Rancangan Penelitian Efektivitas Serbuk Biji Kelor dalam Menurunkan Kadar TSS

\begin{tabular}{|l|c|c|c|c|c|}
\hline \multirow{2}{*}{$\begin{array}{c}\text { Kadar Serbuk Biji Kelor }(\mathbf{B}) \\
(\mathbf{m g} / \mathbf{1 0 0} \mathbf{~ m l})\end{array}$} & \multicolumn{6}{|c|}{ Waktu pengadukan cepat (A) (menit) } \\
\cline { 2 - 6 } & 1 & 2 & 3 & 4 & 5 \\
\cline { 2 - 6 } & \multicolumn{5}{|c|}{ TSS (mg/L) } \\
\hline B1 (100 mg/100 ml) & A1B1 & A2B1 & A3B1 & A4B1 & A5B1 \\
\hline B2 (300 mg/100 ml) & A1B2 & A2B2 & A3B2 & A4B2 & A5B2 \\
\hline B3 (500 mg/100 ml) & A1B3 & A2B3 & A3B3 & A4B3 & A5B3 \\
\hline B4 (700 mg/100 ml) & A1B4 & A2B4 & A3B4 & A4B4 & A5B4 \\
\hline B5 (900 mg/100 ml) & A1B5 & A2B5 & A3B5 & A4B5 & A5B5 \\
\hline
\end{tabular}




\section{PEMBAHASAN}

Penelitian ini digunakan dua variasi yaitu variasi kadar serbuk biji kelor dan waktu kontak selama pengadukan cepat (100 rpm) pada proses koagulasi. Setiap varian kadar serbuk biji kelor dan waktu pengadukan cepat tersebut diuji untuk mendapatkan pengaruh koagulasi yang paling optimal. Masing-masing varian tersebut dilakukan pengulangan sebanyak tiga kali dan diambil hasil rerata. Parameter yang diamati pada penelitian ini ialah persentase pengendapan padatan tersuspensi (TSS). Penelitian ini dilakukan dengan tahapan-tahapan sebagai berikut: a) preparasi sampel (limbah tahu), b) preparasi serbuk biji kelor c) uji variasi kadar serbuk kelor dan waktu kontak terhadap pengendapan padatan tersuspensi (TSS).

Kualitas air limbah ditentukan berdasarkan karakteristik fisika, kimia, dan biologi. Karakteristik sampel limbah yang dipakai dalam penelitian ini dapat dilihat pada tabel 2 .

Pada tabel 2. terlihat bahwa suhu awal limbah cair tahu cukup tinggi. Temperatur erat hubunganya dengan viskositas air yaitu semakin tinggi suhu air maka semakin kecil viskositasnya. Viskositas ini akan berpengaruh pada pengendapan flok. Adanya kenaikan suhu akan meningkatkan gradien kecepatan sehingga flok akan terlarut kembali (Hammer (1997). Oleh karena itu perlu adanya perlakuan untuk mengkondisikan sampel agar stabil sebelum dilakukan proses koagulasi dan flokulasi yaitu dengan cara limbah cair tahu diendapkan selama satu malam. Selain itu, pada tahap ini sebagian TSS limbah cair tahu juga akan mengalami proses pengendapan secara alami dengan bantuan gravitasi bumi. Kemudian TSS yang mengendap tersebut tidak diikut sertakan dalam penelitian ini sehingga diasumsikan bahwa pengendapan TSS selanjutnya hanya dipengaruhi oleh faktor penambahan varian serbuk biji kelor dalam sampel limbah dan waktu kontak pada proses pengadukan cepat.

Serbuk biji kelor yang digunakan dalam penelitian ini berasal dari buah kelor (Moringa oleifera) yang sudah tua. Hal ini dimaksudkan agar kandungan zat aktif yang berperan sebagai koagulan alami yaitu $4 \alpha-$ 4r-rhamnosyloxy-benzil-isothiocyanate sudah terbentuk secara optimal, yang ditandai dengan biji berwarna cokelat dan kering secara alami. Kemudian, biji kelor disortir untuk mendapatkan biji yang masih utuh. Selanjutnya, biji kelor dihaluskan hingga menjadi partikel dengan ukuran \pm 200 mesh. Penghalusan ukuran partikel 
kelor dimaksudkan untuk memperbesar luas bidang sentuh sehingga kontak terhadap partikel koloid akan semakin intens yang akan memberi pengaruh terhadap pengendapan TSS pada limbah cair tahu.

Pengaruh kadar serbuk biji kelor terhadap pengendapan padatan tersuspensi (TSS) dalam proses koagulasi dan flokulasi disajikan pada gambar 1. Dari gambar tersebut terlihat jumlah TSS yang terendapkan semakin meningkat seiring dengan meningkatnya konsentrasi serbuk biji kelor. Penambahan serbuk biji kelor pada semua varian massa telah berpengaruh signifikan dalam pengendapan TSS sampel limbah cair tahu dibandingkan dengan larutan sampel kontrol. Pengendapan TSS mencapai keadaan maksimum pada kadar $0,5 \%(\mathrm{~b} / \mathrm{v})$ dengan hasil maksimal TSS yang terendapkan sebesar 3230 mg/L. Akan tetapi penambahan kadar serbuk kelor selanjutnya yakni sebesar $0,7 \quad \% \quad(b / v)$ memperlihatkan penurunan grafik seperti yang ditunjukkan pada gambar 1. Penurunan grafik juga terjadi pada pada kadar kelor 0,9 $\%$ (b/v) yang menghasilkan endapan TSS sebesar $2630 \mathrm{mg} / \mathrm{L}$. Hal ini mengindikasikan bahwa terjadi penurunan daya koagulasi dari serbuk biji kelor dalam mengendapkan TSS pada limbah cair tahu.

\section{Tabel 2. Karakteristik Limbah Cair Tahu Berdasarkan Sifat Fisika dan Kimia}

\begin{tabular}{|l|c|}
\hline Karakteristik & Keterangan \\
\hline Suhu & $>40^{\circ} \mathrm{C}$ \\
\hline $\mathrm{Ph}$ & $>3,8$ \\
\hline Bau & Busuk dan menyengat \\
\hline Warna & Putih kekuningan \\
\hline
\end{tabular}

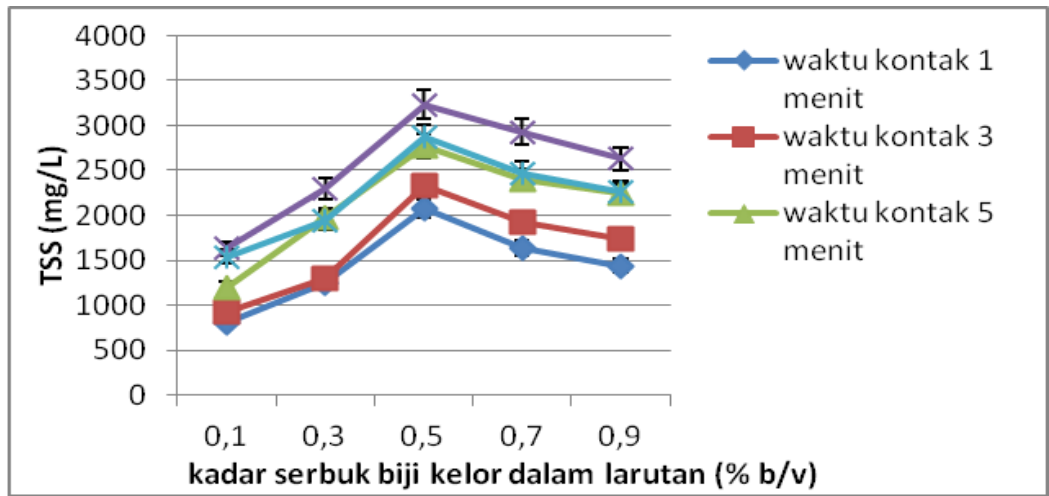

Gambar 1. Pengaruh Kadar Sebuk Biji Kelor Terhadap Pengendapan TSS 
Penurunan jumlah endapan TSS yang terjadi pada konsentrasi tinggi, yaitu $0,7 \%$ dan $0,9 \%(\mathrm{~b} / \mathrm{v})$, dipandang sebagai pengaruh negatif yang ditimbulkan. Penambahan kadar koagulan biji kelor yang berlebih tersebut diindikasikan sebagai pengotor. Hal ini diduga adanya penambahan biji kelor yang berlebih dapat menyebabkan jarak antar partikel biji kelor bertambah sehingga gaya tolak menolak (repulsi) antar partikel biji kelor yang sama bertambah. Pengaruh penambahan kadar koagulan berlebih ditunjukkan pada ilustrasi gambar 2.

Berdasarkan analisis data menggunakan teknik error bar seperti yang terlihat pada gambar 1., menunjukkan bahwa perlakuan pada waktu kontak 1 menit dan 3 menit tidak terdapat perbedaan nyata dimana grafik error bar pada kedua perlakuan tersebut saling berdekatan dan berpotongan yang ditemukan pada perlakuan penambahan kadar kelor sebesar
$0,1 \%(\mathrm{~b} / \mathrm{v})$ dan $0,3 \%(\mathrm{~b} / \mathrm{v})$ dalam sampel limbah. Tidak adanya perbedaan nyata diantara dua garis tersebut dikarenakan kedua garis tersebut mendapat perlakuan yang hampir sama, yaitu kadar serbuk biji kelor dan waktu kontak yang rendah. Sesuai dengan teori tumbukan, kinetika reaksi kimia menyatakan bahwa peluang terjadinya tumbukan antara partikel koagulan dan koloid akan semakin besar seiring dengan pertambahan konsentrasi koagulan dan waktu kontak. Hal serupa juga ditemukan pada waktu kontak 5 menit dan 9 menit yang saling berpotongan pada kadar kelor sebesar 0,3\% (b/v) hingga 0,9 $\%$ (b/v). Sedangkan pada perlakuan waktu kontak 7 menit menunjukkan adanya perbedaan nyata. Semakin panjang garis error bar mengindikasikan variasi data yang besar

pula.

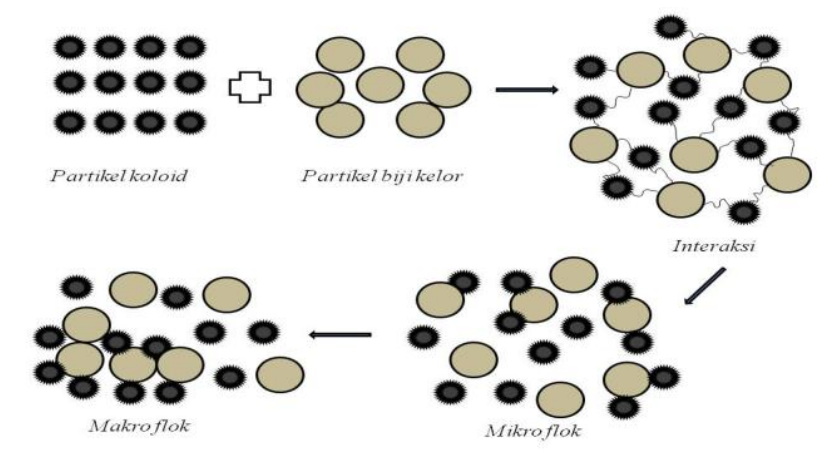

Gambar 2. Ilustrasi Pengaruh Peningkatan Kadar Koagulan Pada Proses Koagulasi-Flokulasi 


\section{Destabilisasi partikel koloid} menggunakan serbuk biji kelor dapat terjadi melalui mekanisme jembatan antar partikel. Biji kelor merupakan polimer (polielektrolit) yang memiliki gugus aktif sepanjang rantainya. Ndabigengesere (1995) dalam Rambe (2009) mengemukakan bahwa zat aktif yang berfungsi sebagai koagulan pada kelor yaitu 4-alfa-4rhamnosiloxy-isothisianate, yang mempunyai gugus aktif isothiosianat. Gugus isothiosianat $(-\mathrm{S}=\mathrm{C}=\mathrm{N})$ dengan 2 ikatan rangkap dan sepasang elektron bebas pada atom $\mathrm{N}$ sangat aktif mendonorkan elektron.

Adanya gugus aktif tersebut menyebabkan partikel koloid dapat berinteraksi dan teradsorbsi. Apabila dua atau lebih partikel teradsorbsi sepanjang rantai polimer, maka suatu jembatan partikel akan terbentuk. Jembatan partikel tersebut kemudian akan bergabung dengan jembatan partikel lain selama proses flokulasi. Penggabungan tiap jembatan partikel menghasilkan pertambahan ukuran dan massa sehingga dapat dengan mudah mengendap ke dasar beaker glass. Partikelpartikel koloid limbah tidak dapat mengendap sendiri dan sulit ditangani oleh perlakuan fisik. Melalui proses koagulasi, kekokohan partikel koloid ditiadakan sehingga terbentuk flok-flok lembut yang kemudian dapat disatukan melalui proses flokulasi.

Ketika koagulan serbuk kelor ditambahkan ke dalam sampel limbah cair maka dilakukan pengadukan cepat (100 rpm). Pengadukan cepat bertujuan untuk membantu proses tumbukan antara koloid dan koagulan. Tumbukan ini menghantarkan pada adsorpsi partikel koloid oleh biji kelor. Biji kelor merupakan senyawa karbon berantai panjang (polimer) dengan berat molekulnya besar 600016000 dalton dan memiliki gugus aktif sebagai adsorben. Partikel koloid akan menempel pada gugus aktif membentuk flok. Penggabungan flok satu sama lainnya membentuk flok yang berukuran lebih besar dan lebih kuat sehingga mengendap. Mekanisme koagulasi semacam ini disebut jembatan antar partikel.

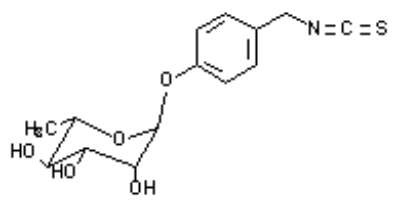

Gambar 3. Struktur 4-alfa-4-rhamnosiloxy-benzil-isothiosianate (Fahey, 2005) 
Pengadukan cepat dilakukan dengan beberapa variasi waktu. Berdasarkan analisis data mnggunakan teknik error bar seperti yang terlihat pada gambar 4., menunjukkan bahwa perlakuan pada kadar $0,7 \%(\mathrm{~b} / \mathrm{v})$ dan $0,9 \%(\mathrm{~b} / \mathrm{v})$ tidak terdapat perbedaan nyata dimana grafik error bar pada kedua perlakuan tersebut saling berdekatan yang ditemukan pada tiap perlakuan varian waktu kontak pengadukan cepat. Hal serupa juga ditemukan pada kadar $0,5 \%(b / v)$ dan $0,7 \%(b / v)$ yang saling berdekatan pada waktu kontak 7 menit. Sedangkan pada perlakuan kadar 0,1 $\%(\mathrm{~b} / \mathrm{v})$ dan $0,3 \%(\mathrm{~b} / \mathrm{v})$ menunjukkan adanya perbedaan nyata.
Pada gambar 4. terlihat pula bahwa waktu kontak selama pengadukan cepat juga mempengaruhi pengendapan kadar TSS limbah cair tahu. Dari gambar tersebut, terlihat bahwa TSS yang terendapkan mengalami peningkatan seiring naiknya waktu kontak pada saat pengadukan 100 rpm. Semakin lama waktu kontak pada proses pengadukan cepat, maka akan memberikan kontribusi yang positif kepada serbuk biji kelor untuk berinteraksi dengan partikel koloid sehingga menghasilkan flok yang lebih banyak. Berdasarkan data hasil penelitian, diperoleh waktu kontak yang paling maksimal dalam memberikan pengaruh terhadap pengendapan TSS yaitu selama 7 menit

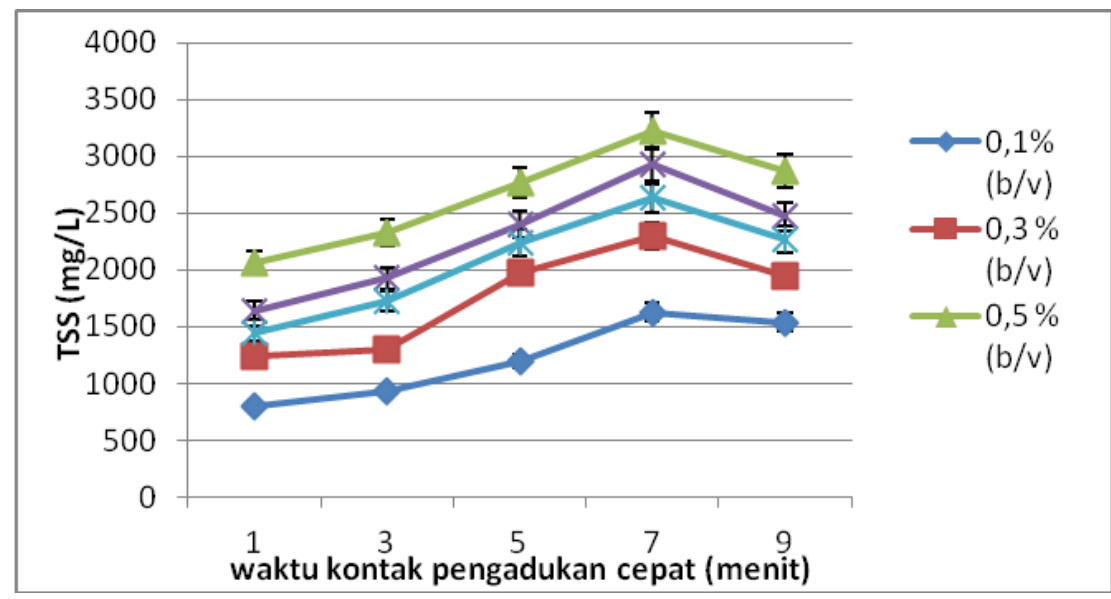

Gambar 4. Pengaruh Waktu Kontak Terhadap Pengendapan TSS 
Disisi lain, terjadi penyimpangan pada waktu kontak selama 9 menit, yang ternyata tidak berkolerasi linear terhadap hasil TSS yang terendapkan seperti yang terlihat pada gambar 8. Penurunan hasil TSS yang terendapkan tersebut diduga disebabkan oleh pecahnya sebagian flok yang telah terbentuk akibat terlalu lama proses pengadukan cepat. Pecahnya sebagian flok tersebut disajikan dalam ilustrasi pada gambar 5 .

Tahap berikutnya yaitu pengadukan lambat (40 rpm) selama 10 menit. Hal ini bertujuan untuk memberikan waktu untuk terjadi proses flokulasi yaitu terbentuknya flok-flok yang lebih besar sehingga membentuk endapan. Pada tahap ini flokflok mikro yang dihasilkan dari proses pengadukan cepat dibawa ke dalam proses kontak sehingga bertubrukan satu sama lain akibatnya flok-flok mikro bergabung dan lengket sesamanya serta tumbuh membentuk flok-flok yang ukuran massanya lebih besar sehingga dapat mengendap, dan proses pemisahan akan lebih mudah dilakukan.

Pengendapan TSS pada limbah cair tahu berbanding lurus terhadap penurunan kekeruhan. Hal ini disebabkan karena komponen utama yang mempengaruhi tingkat kekeruhan limbah cair tahu ialah TSS. Artinya bahwa jika jumlah TSS dalam limbah bisa dikurangi dengan cara pengendapan, maka akan dapat menjadi solusi dalam penjernihan air limbah.

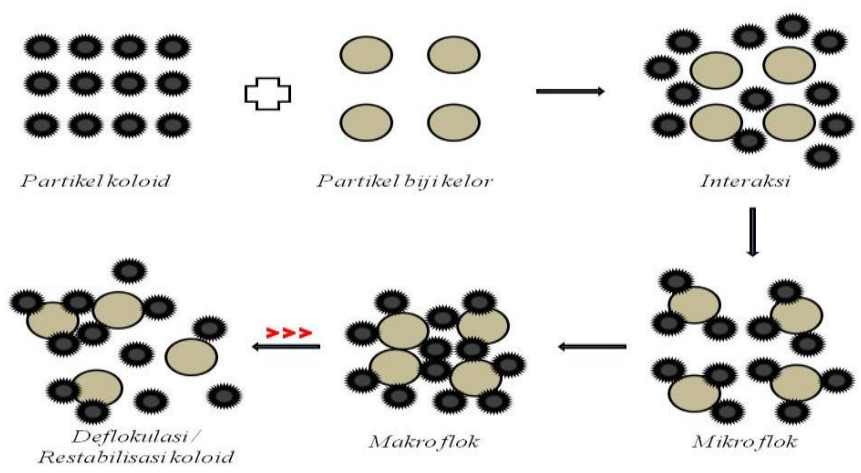

Gambar 5. Ilustrasi pengaruh peningkatan waktu kontak pada proses koagulasi-flokulasi. 


\section{KESIMPULAN DAN SARAN}

\section{Kesimpulan}

Berdasarkan hasil penelitian yang telah dilakukan, dapat disimpulkan bahwa:

1. Kadar serbuk biji kelor yang digunakan sebagai koagulan pada limbah cair tahu memberikan hasil yang optimum pada $500 \mathrm{mg} / 100 \mathrm{ml}$ sampel limbah dan waktu kontak pada pengadukan cepat selama 7 menit dengan kecepatan $100 \mathrm{rpm}$.

2. TSS yang terendapkan pada kondisi optimum sebesar $3230 \mathrm{mg} / \mathrm{L}$.

3. Penggunaan biji kelor sebagai koagulan limbah cair industri tahu efektif dalam mengendapkan TSS.

\section{Saran}

1. Penentuan kondisi optimum koagulasi sebaiknya dilakukan dengan prosedur jar test karena dapat meminimalisir kesalahan dalam analisis dengan pengadukan yang stabil.

2. Mengingat hasil pengendapan yang diberikan cukup besar maka perlu dilakukan uji lebih lanjut mengenai parameter lain seperti BOD, COD, kekeruhan sebagai pengembangan penelitian menggunakan koagulan alami yang ramah lingkungan dan ekonomi.

\section{UCAPAN TERIMAKASIH}

Penulis mengucapkan terima kasih kepada pengelola laboratorium Agronomi Fakultas Pertanian Universitas Bengkulu atas izin pelaksanaan penelitian.

\section{DAFTAR PUSTAKA}

Amdani, K. 2004. Pemanfaatan Biji Kelor (Moringa oleifera) Sebagai Koagulan Pada Proses KoagulasiFlokulasi Dan Sedimentasi Limbah Cair Pencucian Jeans. Tesis Program Studi Pengelolaan Sumber Daya Alam Dan Lingkungan. Universitas Sumatera Utara: Medan (diakses dari http://repository. usu.ac.id pada 5 September 2012)

Fahey, Jed W. 2005. Moringa oleifera: A Review Of The Medical Evidence For Its Nutritional, Therapeutic, and Prophylactic protpertis. Artikel (diakses dari http://www.tfljournal.org pada 27 Oktober 2012)

Hammer. 1997. Water and Wastewater Technology, Second Edition. John Willey and Son Inc: New York (diakses dari http://www.google.co.id/ books pada 14 Oktober 2012)

Khasanah, Uswatun. 2008. Efektifitas Biji Kelor (Moringa oleifera, LAMK) Sebagai koagulan fosfat Dalam limbah cair rumah sakit (Studi Kasus di RSU Dr. Saiful Anwar Malang. Tesis. Universitas negeri malang: malang (diakses dari http://lib.uin-malang.ac.id pada 27 Oktober 2012)

Montgomery, M.J. 1985. W ater Treatment Pronciples and Design. Inc John Wiley dan Sonc: New York (diakses 
http://www.google.co.id/books pada 10 Oktober 2012)

Ndabingengsere, A dan K, Subba Narasiah. 1998. Quality Of Water Treated By Coagulation Using Moringa Oleifera. Journal water research 32, 3:781-791

Pudjaatmaka, A.Hadyana, dkk. 2002. Kamus Kimia. Balai Pustaka: Jakarta

Rambe, Ahmad Mulia. 2009. Pemanfaatan Biji Kelor (Moringa Oleifera) Sebagai Koagulan Alternatif Dalam Proses Penjernihan Limbah Cair Industri Tekstil. Tesis Program Studi Teknik Kimia. Universitas Sumatera Utara: Medan (diakses dari Error! Hyperlink reference not valid. pada 5 September 2012)
Robinson, Odom, Holtzclaw. 1997. General Chemistry. Houghton Mifflin: New York

Sumardjo, Damin. 2006. Pengantar Kimia. Penerbit Buku Kedokteran (EGC): Jakarta

Sutherland, J.P, Folkard, G.K, Mtawali, M.A. dan Grant, W.D. 1994. Moringa oleifera as a natural coagulant. Artikel (diakses dari http://www.miracletrees.org pada 10 September 2012)

Wiryani, Erry. 2005. Analisa Kandungan Limbah Cair Pabrik Tempe. Error! Hyperlink reference not valid.diakses dari http://eprints.undip.ac.id pada 5 September 2012 